\title{
M.V. Kostennikov, A.V. Kurakin \\ Corruption prevention in state administration and civil service system in the Russian Federation
}

\begin{abstract}
The article views legal and organizational issues in corruption prevention in state administration and civil service system. The article calls attention to how most of the organizational and administrative issues cause corruption growth in the civil service system. As of today, we have to acknowledge that the existing legislative measures are not sufficient to prevent corruption, and in anticorruption policy we can see domination of the political factor and political orientation. These issues hinder the implementation of all existing legislative means aimed at corruption prevention.

The question of corruption prevention throughout the activities of public authorities and state administration has acquired a global and systemwide character. Corruption is an immediate threat to the national safety. It hinders democratic and civil society institutions to develop; the citizens to realize their constitutional rights in the sphere of education, public healthcare, social maintenance and property relations. Besides, corruption has a negative impact on the growth of economic and financial sector and all infrastructure of the Russian state.

It is worth accentuating that corruption in the activities of public authorities and state administration contributes to the growth of organized crime, encourages the development of extremism and terrorism, threatens realization of national projects and harms all state and legal reforms which are currently being carried out in our country. The presence of all these and some other issues proves that designing of an administrative and legal mechanism of corruption prevention throughout the activities of civil servants and building of the institute of administrative justice is objectively necessary.

As we can see from the experience in carrying out state and legal reforms, as well as from the practice of law enforcement activities in the sphere of corruption prevention, corruption arises in those spheres of public authorities and civil servants activities in which the status is not fully described and where
\end{abstract}

KOSTENNIKOV, Mikhail Valerjevich - LLD, professor at All-Russia Institute for professional retraining of the officers of MOIA of the Russian Federation.

142008, Russia, Moscow Oblast' town of Domodedovo, 3 microraion Aviatsionny, ul. Pikhtovaya.

[m-2263768@yandex.ru]

KURAKIN, Aleksey Valentinovich - LLD, professor at All-Russia Institute for professional retraining of the officers of MOIA of the Russian Federation.

142008, Russia, Moscow Oblast' town of Domodedovo, 3 microraion Aviatsionny, ul. Pikhtovaya.

[kurakinaleksey@gmail.com] 
there are no administrative procedures set to provide services to the citizens and legal entities. The experience of corruption revealing shows us that it arises in the spheres where civil servants realize organizational, executiveadministrative, control and supervising, jurisdictional and licensing powers. Which is why it is necessary, especially today, to improve administrative and legal regime of activities of civil authorities and administration.

Key words: corruption, prevention, fight, service, civil servant, administration, system, servant, prohibition, responsibility, control, threat.

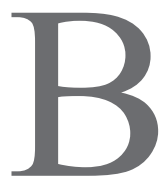
oth in our country and abroad one of the reasons of corruption growth in administrative activities of civil servants is poor quality of normative and legal framework regulating their activities. At the present time we have to acknowledge that both legislative and normative framework in effect are not quite efficiently regulating executive-administrative activities of the servants of public authorities and administration, which provide the citizens and legal entities with corresponding public services (licenses, permits, opinions, etc.). The above-mentioned reasons have an objective nature in many respects, whereas there are a number of issues of subjective nature, and these are very difficult to be affected by means of law.

In this respect it becomes justifiable and necessary to use experience of foreign countries to resolve most of the problems in the sphere of corruption prevention in civil service of the Russian Federation. Besides, the whole administrative and legal mechanism aimed at corruption prevention has already been developed by a number of industrially developed countries and some or other model of administrative justice is already functioning there. Administrative justice, whose main goal is the improvement of the lives of the citizens, must fulfill three fundamental tasks:

- design an effective (objective, free of charge, efficient) mechanism of rights protection and legal interests protection of the subject without authority (citizen, individual entrepreneur, public association) on cost cutting (time, money and health saving) principle;

- raise trust of the public on the public agencies of executive power (reduce the level of bureaucracy and corruption);
- make the courts less busy and relieve the courts from the functions of the administrative and jurisdictional body, which are alien to their activities of the courts ${ }^{1}$.

In order to establish an institute of administrative justice it is necessary to follow the regulations of the UN Convention against corruption and the Convention of the Council of Europe about the corruption criminal liability, and recommendation of the Group of States against Corruption (GRECO) by passing the federal and constitutional law "About the federal administrative courts in the Russian Federation».

Furthermore, legal administrative and organizational framework for corruption prevention already exists almost in all foreign states. And it allows reducing the level of corruption so that the latter does not constitute a threat to the individual, society and state. Experience of legal and administrative regulation of corruption prevention in public service systems of foreign states demonstrates that in most of them they are working at the mechanisms of corruption prevention in civil service, they use a number of legal and organizational means aimed at elimination of conditions and reasons encouraging the presence of corruption risks. Establishing universal approaches to determination of the mechanisms of anticorruption safety in the activities of the state and municipal services becomes very important in corruption prevention. The contents of the above mentioned approaches required that many foreign countries had to draft a number of documents, including:

\footnotetext{
Panova I.V. Administrative jurisdiction in Russia: searching for determination, history of the question: extract // Bulletin of the Supreme Arbitration Court of the Russian Federation. 2009. № 3. P. 44.
} 
- guidelines for acts about organization of anticorruption examination of the drafts of the regulatory legal acts at various federal executive authorities. A model statement allows unifying the process of work organization of anticorruption examination of the drafts of the normative legal documents at various federal executive authorities;

- methodological recommendations on work organization for corruption prevention in the civil service system. The contents of methodological recommendations must present description of certain mechanisms, which will guarantee measures, which are provided by the anticorruption legislation. These measures are related to verifying of personal and other information provided by the subject when he/she takes state service. It includes accuracy of information about income, estate and estate liability, which civil servants along with their spouse and minor children must provide.

It is worth mentioning that corruption is a transnational phenomenon, which is why the level of corruption in one country may affect the level of corruption in a neighboring country, including legitimacy and law and order in other states. Which is why it is necessary that several states and international organizations alike join efforts in corruption prevention.

Thus, at the present time it is necessary to improve forms and methods of giving mutual consultations on corruption prevention issues; to create a database of anticorruption legislation and anticorruption means; cooperate in headhunting and training of the staff who would participate in activities aimed at corruption prevention and in writing anticorruption standards describing the ethics and norms of civil servants conduct.

Design of administrative mechanism of corruption prevention in the civil service systems of foreign countries supposes creation of the system of constant monitoring: of observation of legal normative and ethical requirements by civil servants; of the wealth of the civil servant and their family members; of the execution of the official duties by civil servants when there is corruption risk (with the opportunity to eliminate such risks); of the activities with state procurements. Monitoring of the above-mentioned criteria requires designing of the mechanisms for collaboration between the executive body and the law enforcement agencies, taxing authorities, which execute corresponding control and supervision.

At the present time it is necessary to control the mechanisms of prosecution of legal entities for corruption offences. The analysis of the Administrative offences Code of Russia demonstrates that only one provision on liability for illegal gratification on behalf of the legal entity is not enough. It is necessary to include other elements of crime, which will cover liability of legal entities for breaching of the federal law from December 25, 2008 «About corruption prevention» ${ }^{2}$.

As it has been mentioned, a number of foreign states already have quite detailed mechanisms for solving the conflict of interests in the civil service system, and this allows minimizing corruption risks in administrative activities of the civil and municipal servants. At the present time it is needed to foresee the mechanisms to be used to realize measures of legal liability (administrative liability, criminal liability, disciplinary liability) for the members of committees for solving conflicts of interests. To create comprehensive mechanisms for solving the conflict of interests in the civil service system it would be appropriate to complete the Labor Code of Russia with regulations related to solving the conflict of interests in the activities of those employees who have to cooperate with the civil and municipal servants.

It would be quite justified if the legislation about the civil service of the Russian Federation vests the same rights to the legal and physical entities along with the civil servant for inquiry of an internal investigation to disproof certain facts, because legal interests of the legal and physical entities are very often discriminated by corrupted behavior of the civil servants. The subjects participating

\footnotetext{
2 Legislation Bulletin of the Russian Federation. 2008. № 52 (Part 1). P. 6228.
} 
in a certain procedure must have free access to the data of the internal investigation, furnish proof, be kept informed about all taken decisions and have the right to appeal the latter either to the court or in administrative proceedings.

In order to minimize the threat of corruption risks in the civil service system we need to develop and efficiently use the anticorruption campaigns. These campaigns must include: consecutive application of administrative regulations in official activities of the public authorities and state administration servants; proper definition of the rights, responsibilities and legal liability of public bodies and also their employees; introduction of accurate procedures for taking administrative decisions; usage of methods to analyze legal acts with respect to corruption; description of antisocial nature of corruption and its negative impact on society, state and its citizens.

Based on the above, we can positively state that administrative justice may substantially contribute to corruption prevention as well as foster better solving of legal conflicts, which arise between the individual and the servant of public and administration authorities.

Corruption along with bureaucracy in combination with low ethics of many members of the government machine distorts the proclaimed national policy together with the legislative framework of the civil service. Poor quality of organization of activities of administrative bodies with the inherent social environment, their functioning style, mutual cover-up, etc. result in becoming corrupted themselves instead of fighting corruption. According to V.V. Luneev «... corruption has become our constitution, and when there is no prosecution - it becomes an every day routine» ${ }^{3}$.

The efforts, which are taken by the State in the matter of corruption prevention in the civil service system, are fully justifiable. Corruption presents a serious threat to the activities of public authorities, corruption discredits government institutions, giving way

\footnotetext{
3 Luneev V.V. Corruption in Russia // State and Law (Journal). 2007. № 11. P. 20.
}

to the legal nihilism of the population. On the whole corruption in civil, military and law enforcement services presents a serious threat to the safety of the Russian state. According to A.G. Khabibulin «... corruption indicates the level of safety of the society» ${ }^{4}$. On various levels in the civil service system corruption creates environment favorable for terrorist acts, growth of extremism, encourages legalization of illegal income. All of the above mentioned and some other issues arising from corruption cause an immediate threat to the security of the person, society and national safety. Corruption seems to be a factor, which deteriorates the process of building the civil society in Russia. At the present time corruption challenges the State and the State cannot stay inactive anymore waiting until corruption penetrates into even more spheres.

However, it is obvious that it is necessary to find out the reasons for corruption and its growth, if you will, its genesis, to be able to carry out efficient activities aimed at corruption prevention in the civil service system.

According to many surveys, carried out in this field, there are many reasons of corruption existence in the civil service system of the Russian Federation. The results of the survey carried out by the Institute of Sociology of the Russian Academy of Sciences show what causes the existence of corruption according to what people of the Russian Federation think: the civil servants' greed and low morals - 70, 1\% respondents answered; corruption challenges state's efficiency $63,3 \%$ respondents answered; $37,2 \%$ of the respondents think that low level of legal culture and legal nihilism also encourage corruption. Clan system and favoritism to family members in the civil service system favors corruption according to $39,9 \%$ of the respondents. Besides, legal ignorance of the civil servants also may be referred to the reasons causing corruption according to $13,7 \%$ of the respondents, and 4,2\% doubted how to answer what causes corruption and only

\footnotetext{
Khabibulin A.G. Corruption as a threat to national safety: methods, issues and ways of solving them // Journal of Russian Law. 2007. № 2. P. 45.
} 
$1,1 \%$ named other reasons of corruption. It is interesting to note that only $2,5 \%$ of the respondents think that corruption is evil.

It seems that the reasons of tremendous corruption in the civil service system can be caused by inconsistency of administrative reforms, pointless and constant reforming of the civil service; the inefficient staff policy in the civil service system, poor professionalism of many (including high ranking officers) civil servants; inefficient application of administrative procedures. Besides, corruption arises also as a result of absence of proper mechanism of a career growth of the civil servant; low salary of most of the servants; lack of competitive conditions and alternatives when appointing to the important posts in the civil service, which are susceptible to corruption most; lack of efficient mechanisms of legal liability in legal administrative sphere of activities of the civil servant; repeating of the functions of various government agencies both on the federal and regional levels; lack of competence differentiation both on federal level and on the level of the subjects of the Russian Federation in the mechanism of realization of the means of corruption prevention in the civil service system; insufficient consistency in the mechanism of corruption prevention in the civil service system; political orientation and environment in the matter of corruption prevention in the civil service system of the Russian Federation. Once the corruption reasons have been determined, we can design the corresponding mechanism, which will allow turning corruption impact into not threatening the public safety on such a big scale.

Corruption in the civil service system was known as a social phenomenon long ago. The phenomenon is present to a various extent in any society, under any political and economical regimes. Various forms of corruption existed even in ancient civilizations. There was a time when a number of industrialized foreign countries (largest economies) had to face corruption as a global danger. Reducing the level of corruption in the sphere of public administration encouraged economic development and wealth of the population in this states. And today we can see considerable achievements in the matter of corrup- tion prevention in many states. Among these states we can mention: Sweden, Denmark, Finland, Switzerland, Italy, Germany, Great Britain, Canada, Japan, USA. Many South Asian countries also show certain achievements in the matter of corruption prevention in the civil service system. The Baltic States have achievements in corruption prevention in the civil service system.

It is necessary to mention that those countries, which today demonstrate considerable achievements in the matter of corruption prevention, have been working on corresponding legal measures for many years to achieve those. As a rule corruption prevention can be successfully achieved if the whole variety of various legal means is used: constitutional means, international-legal means, criminallegal, information, etc. In other words legislation of various fields contained anticorruption instructions before, but only application of the total range of legal means substantially contributes the matter of corruption prevention in the civil service system. In consideration of the foregoing foreign experience in corruption prevention can and should be used when creating a variety of legal means aimed at corruption prevention.

It is fair to say that it is required to apply the whole range of legal means of effective corruption prevention in the civil service system of the Russian Federation. Still the core in the mechanism of corruption prevention in the civil service system of the Russian Federation should be the administrative legal means. This is due to the ability of the rules of administrative law to establish the regime of state service realization, and they also establish the regime of public administration on the whole, and they are used to decide the order of rendering of the public services to the physical and legal entities, the order of relationship between different subjects in the sphere of executive-administrative activities.

We can refer the following to the administrative legal means of corruption prevention: administrative restraints related to the civil service; means of the conflict of interests regulation in civil service; transparent office regulations of the civil servant, competitive appointment for civil service posts; creation 
and obligatory usage of the candidates pool; considering alternatives while interviewing the candidates for the civil service posits; setting a probationary period for the candidates for the civil service posts; mechanism of cooperation with the inherent security units aimed at approval of candidates for posts of responsibility in the civil and law enforcement services; assigning a special status to the posts that are perceived as the most vulnerable to corruption in the civil service; social guarantees referring to the regime and status of the civil servant; incentive and rewarding of the civil servants; outlining possible career growth stages of the civil servant; dismissal from office in cases when conflicts of interest arise; competency testing; regime of official discipline rules at civil service; administrative control of official activities of the civil servants; control of the taxing authorities of the wealth of the civil servant and their family members; disciplinary and administrative responsibility of the civil servants; mechanism of declaring income, property and property relations of the civil servant; labor remuneration of the civil servants; rotation of office in the civil service system, etc.

Federal law from October 30, 2008 «About corruption prevention» ${ }^{5}$ among other administrative legal means of corruption prevention mentions the responsibility of the civil and municipal servants to inform about any attempts to corrupt them (Page 9). The law provides protection remedy for the civil servant who reported the fact of being addressed by a corrupter, or who reported about other corrupted servants. For further development of the mechanisms of participation of the citizens and the institutes of the civil society in corruption prevention campaigns the Federal law «About the corruption prevention» needs to be completed with the regulations providing safety to the citizens and public organizations who reported corruption offences in the public service system.

Speaking about the importance of administrative legal means of corruption prevention, we should understand that they are needed to

\footnotetext{
Legislation Bulletin of the Russian Federation. 2008. № 52 (Part 1). P. 6228
}

prevent corruption misdemeanor from turning into act in the first place, because then it will be a serious social danger and it will be considered a corruption offence. The criminal liability for corruption offences is provided by the Criminal Code of the Russian Federation: abuse of administration of power (Article 201), commercial bribery (Article 204), abuse of office (Article 285), exceeding official authority (Article 286), bribe taking (Article 290), bribery (Article 291), illegal enterprise (Article 289), etc.

Further on, we shall speak more about some of the administrative legal means of corruption prevention in the civil service system of the Russian Federation.

For instance, we should note that the Federal law from June 27, 2004 «About the civil state service of the Russian Federation $\rangle^{6}$ contains the whole range of administrative legal means of corruption prevention in the civil state service of the Russian Federation. But we can hardly say that its provisions present comprehensive anticorruption remedy. The situation is gradually changing. At the present time the Russian President approved the list of executive posts in civil service, state corporations and funds, which bind the citizens to file declarations on their income, property and expenses. Besides this, there is an order of providing corresponding data to taxing authorities, as well as publishing this information in mass media, there is the order of income reporting, expenses and property reporting by the candidates holding the executive posts.

Federal law «About the state civil service of the Russian Federation» also decides the order of labor remuneration of the civil servants. According to the research, credibility (prestige) of civil service in Russia can be restored partially due to a pay raise of the civil servants, and one of the efficient administrative legal means of corruption prevention in the civil service system of the leading foreign countries is the financial security of the civil servants. High labor remuneration guarantees maintenance of highly qualified and honest staff.

\footnotetext{
Legislation Bulletin of the Russian Federation. 2004. № 31 (Part 1). P. 2063.
} 
Another means, which is worth pointing out, is the rotation in office. The staff rotation in office procedure is one of the most efficient means of corruption prevention in the civil service system. Federal law «About state civil service of the Russian Federation ${ }^{7}$ declares the staff rotation in office one of the fundamental principles for staff policy of the civil service (Clause 1, Page 60). Scientific works also suggest the need to improve the procedure of rotation in office. For instance, A.F. Nozdrachev suggests creation of a more flexible system of rotation in office, especially what concerns those civil servants, who are in a constant immediate contact with the population and commercial organizations ${ }^{8}$.

It would be appropriate in this case to adopt the experience of foreign countries, for instance of Germany, where according to the law «About corruption prevention» (1997) administration of the agency of civil service must oversee all situations related to corruption prevention, find posts of the civil, which are mostly susceptive to corruption and carry out campaigns aimed at prevention of possible corruption offences. It is worth mentioning that a very serious recruitment policy is used to hire employees for such posts. All the candidates must be morally and psychologically sound, and they are usually replaced every five years. Chinese rotation in office system suggests that civil servants should change locations and posts. State agencies of the Chinese Public Republic must always have some vacant posts in reserve to be ready to accept civil servants in rotation of office. The above-described experience is worth applying within the mechanism of administrative legal regulation of the rotation in office in the civil service system of the Russian Federation. The importance of finding posts that are perceived as the most vulnerable to corruption in certain types of civil service is described in many scientific works. According to V.M. Koryakin «... about the necessity and options of differentiation of the

\footnotetext{
Legislation Bulletin of the Russian Federation. 2004. № 31 (Part 1). P. 2063.

8 Nozdrachev A.F. Legal means of corruption prevention // Journal of Russian Law. 2004. № 9. P. 165.
}

military posts due to their level of vulnerability to corruption?

Federal law from December 6, 2011 «About making amendments in certain legislative statements of the Russian Federation appealing to rotation in office in state civil service ${ }^{10}$ says that civil servants rotation in office is carried out to make civil service more efficient and to prevent corruption by appointing civil servants to other posts in civil service, including transferring to another civil authorities.

Rotation in office of civil servants should be realized within one group of civil posts. The official salary should not be smaller the one attached to the previous civil service post and should be adequate to the qualification, field education and length of civil service or work (service) with the background experience of the civil servant. The order of civil servants rotation in office prescribes that the civil service post has to be held from three up to five years.

Speaking about the nature of corruption itself in the civil service system, it is worth mentioning that various elements of an offence can be called corruption when we speak about misuse of the powers of office by the civil servants out of their mercenary motives or personal interests which result in granting illegal advantages to physical and legal entities in various spheres of life.

When we deal with corruption on the state level, the subject of corruptive relationship is the person empowered with executive-administrative authorities, control and supervising powers, licensing powers and also rule making powers, which this person is using with the intentions of their own and in their own interests. Besides, in some cases we can refer such activities corruption offences as misuse of authority and credibility by the servants with the purpose to influence the spheres beyond their competency.

It is important to take into consideration the economic aspect in the civil service system in order to create the concept of application of ad-

\footnotetext{
Koryakin V.M. Corruption in Armed Forces: theory and practice of prevention. M., 2009. P. 100.

10 Legislation Bulletin of the Russian Federation. 2011. № 50. P. 7337.
} 
ministrative legal means of corruption prevention in the civil service system of the Russian Federation, the same concerns the building of its realization mechanism. As we already mentioned it is due to the deteriorating impact of corruption on the economy that the State and the society incur considerable losses, the State has a budget gap every year, huge funds are washed away from the national economy and financial system. Besides, corruption encourages the goods markets getting monopolized. The above-mentioned points demonstrate the relation of corruption in the civil service system to the economy of the sate as well as to its financial system and infrastructure.

Corruption in the civil service system has an immediate relation to the political system of every State. In the classical age corruption was exclusively viewed as a political phenomenon. Today corruption is still one of the widely spread means of power struggle. Political corruption has a rather complicated structure and serves as a favorable environment for other types of corruption, especially administrative, which almost every citizen has to deal with when he applies to the civil servant in the sphere of executive-administrative activities.

Generally speaking, all corruption types, which are taking place in the civil service system of the Russian Federation are immediately interrelated. This is why we need a comprehensive system of organizational, legal and administrative means of corruption prevention in various types and on various levels of the civil service of the Russian Federation. It can be explained by disability to achieve positive results in the matter of reducing the level of corruption if you focus on a single area or segment of the civil service. In other words, administrative legal means of corruption prevention should be of comprehensive and systematic character, should concern every civil servant and any other public authority.

Besides, administrative legal means of corruption prevention should concern not only the civil servant, but also their close relatives alike, and those people who worked in the civil service before, and also people and enterprise entities involved into the sphere of executive activities of the civil servant.
Another foul aspect of corruption is the fact that corruption in the civil service system of the Russian Federation stimulates unfair relocation of resources (reassignment of funds) in favor of certain corporate and social groups at the expense of most vulnerable segments of population. Corruption prevents the citizens from receiving compulsory free of charge state services. And on the contrary, corruption in jurisdictional, monitoring, criminal and procedural activities creates the environment for terroristic acts, growth of extremism and money laundry.

In order to create the system of administrative means of corruption prevention it is necessary to take into consideration international legal and European standards of corruption prevention together with the successful practice of foreign countries in the field in question. Recently a number of international acts aimed at corruption prevention have been ratified by the Russian Federation. A significant document in this field is the Convention of the United Nations Organization «Against Corruption», the Convention of the Council of Europe «About the criminal liability for corruption».

However, we can't say yet that the normative potential of these documents has been fully used.

Federal law from December 25, 2008 «About corruption prevention»" ${ }^{11}$ stresses on the liability of the civil and municipal servants to provide information about their income and property and property relations (Article 8).

It is worth pointing out that Federal law from December 3, 2012 «About the control for the compliance of the expenses of the individuals holding the civil service posts and other parties with their income» came in effect from January $1,2013^{12}$. For reasons of corruption prevention the law formulates legal and organizational foundations for the realization of control for the compliance of the expenses of the individual holding the civil service post (or other person) with the expenses of their

\footnotetext{
11 Legislation Bulletin of the Russian Federation. 2008. № 52 (Part 1). P. 6228.

12 Rossiyskaya Gazeta. 2012. December, 5.
} 
spouse and minor children to the total income of this individual, his or her spouse for the last three years prior to the deal. The law also determines the category of citizens in whose respect the control of expenses is exercised, the order of control of expenses and the mechanism of turning the property into the income of the Russian Federation, if the income has not been reported and which acquisition has not been proved as legal.

The sufficient ground for checking the expenses of the person holding (held) certain posts, of his or her spouse and minor children may be the information that this person, his or her spouse or minor children made a deal to purchase land, other type of real estate, a vehicle, securities, shares (stock, a share in equity (or join stock) capital of organizations) at the price exceeding total income of this person, his or her spouse and their minor children for the last three years prior to the deal. In case if the breach of the law is revealed, administrative or some other offense was stated while exercising the control over the expenses of the person holding the corresponding posts, of his or her spouse and minor children, the documents are forwarded on the third day after the check up was completed by the person who initiated the procedure to the corresponding competent public authorities. Prosecutor General of the Russian Federation or prosecutors subject to him bring the received documents to court for legal action following the order established under legislation about civil procedure, apply to court with the lawsuit to turn the land, other type of real estate, a vehicle, securities, shares (stock, a share in equity (or join stock) capital of organizations) which has not been reported and which acquisition has not been proved as legal into the property of the Russian Federation.

Speaking about the subjects of corruption prevention, we can mention that various subjects are taking part in ensuring the realization of the corresponding administrative legal means. Much depends on their efficiency. Thus it is needed to improve the relationship between various law enforcement authorities, which are related to the mechanism of corruption prevention. In relation to this it would be reasonable to draft and issue the Federal law «About the foundations ensuring the inherent security of the law enforcement and controlling authorities of the Russian Federation». Such a legislation act could create the legal framework for ensuring inherent safety of the law enforcement and controlling authorities.

We should also improve the system of the process management of corruption prevention in various authorities of state power. Besides, it will be required to make a list of state service posts that are most vulnerable to corruption. Some civil service posts, which can be referred to those that are perceived as the most vulnerable to corruption, may need the approval of the president of Russia. It is necessary to specify the register of such posts both on federal and regional levels in the system of civil service, law enforcement service and military service. The persons holding the posts from this list should regularly go through rotation in office. Besides, it would be fully justified to impose a number of prohibitions and liabilities upon the immediate relatives of the person holding the post that is perceived as the most vulnerable to corruption in the civil service system of the Russian Federation.

Also for the purposes of improvement of the mechanism of corruption prevention it would be fully justified to make amendments in the administrative legislation in various directions. For instance at the present time it is necessary to set liability of the physical parties for the intentional misinterpretation about corruption in the Code of the Russian Federation on Administrative Offences.

It is necessary to welcome that such legislation acts as the Code of the Russian Federation on Administrative Offences and Labor Code of the Russian Federation began to be amended with anticorruption instructions. The above mentioned legislation acts ensure realization of the legislation about the civil service and corruption prevention. Thus, the Code of the Russian Federation on Administrative Offences sets the liability for illegal rewarding on behalf of the legal entity (Article 19.28), and also for illegal employment of the civil servant (former civil servant) (Article 19.29). 
In our opinion, there is a good reason to draft the law concerning a greater role of usage of the civil state means in the mechanism of corruption prevention in the civil service system. Instructions of the Civil Code of the Russian Federation are not fully used at the present time in the mechanism of corruption prevention in the civil service system. This situation cannot be called satisfactory, because administrative legal means are mostly interrelated with the civil legal means in the mechanism of corruption prevention in the civil service system. Which is why these means should be used as a whole.

In order to enhance the effect of the ethical norms in the civil service system, it would be fully justified to introduce «the Code of service ethics of the state and municipal servants of the Russian Federation», and to draft amendments to department normative legal acts, which regulate the order of service conduct of the civil servants. Today we have such codes of service conduct in various spheres of management, as well as in working and professional activities. Thus, we can mention the code of ethics of service conduct of realtors, accountants, journalists, appraisers, psychiatrists and others ${ }^{13}$.

In its turn, the law "About the state civil service of the Russian Federation» says that every civil servant must: execute his duties faithfully, with a high level of proficiency, based on the essence and meaning of his professional service activities constitute acknowledgement, respect and protection of the rights and liberties of the man and citizen; carry out their professional service activities within the framework set by the legislation of the Russian Federation in the competence of the state authority; do not prefer above the others particular public and religious associations, professional or social groups, organizations and citizens; do not take steps driven by their personal motives, property (financial) or other interests, which hinder their faithful execution of their duties; respect the restrictions set by the law for the civil servants; remain neuter, which eliminates commitments to the

13 Malinovsky A.A. Code of professional ethics: definition and legal meaning // Journal of Russian Law. 2008. № 4. P. 39. political parties, public associations, religious communities and other organization putting them under pressure in their professional service activities; do not commit acts, which discredit their dignity; show respect in communication with the citizens; show respect to ethical habits and traditions of the peoples of the Russian Federation; take into consideration cultural and other peculiarities of various ethnic and social groups, including confessions; encourage interethnic and interfaith harmony; do not let conflicts arise, which can do harm to their reputation or discredit the state authority; follow the set rules of speaking in public and providing information for internal use only (Article 18).

For perfection of the law enforcement activities in the sphere of corruption prevention in the civil service system it is necessary to eliminate double functions of various public authorities, and of executive authorities in the first place. A number of unreasonable contacts between the state servants and the citizens and the representatives of the legal entities should be reduced to a minimum. In some spheres of state services it is needed to create and provide with a new normative framework of standards such means of protection of the citizens and legal entities, which will help them to feel more or less confident in their relationship with the civil servant who is working with their documents or provides state services. Especially it is necessary to provide a new normative framework for the principle of "positive administrative silence» in the legislation of licensing, registration and technical regulation. The essence of this principle implies that if any duly made and filed request for the license extension, registration, etc. by the citizen or legal entity receives a lack of response, the documents will be considered to be valid and automatically extended. In other words, the decision is taken for the benefit of the requester. This scheme might to some extent minimize unreasonable relationship between the individual, entrepreneur and the corresponding official servant. The above-described mechanism (after appropriate work and approbation) may be used as another means of corruption prevention in the civil service system of the Russian Fed- 
eration. For perfection of the law enforcement activities in the sphere of corruption prevention, certain amendments need to be added to the legislation, which regulates social relations in the civil service system of the Russian Federation.

Besides, it might be reasonable to set a statement in the Federal law from May 27, 2003 «About the civil service system of the Russian Federation ${ }^{14}$, prohibiting the employee to make deals not from their own names but under the pseudonym and with help of the fictitious person. Such deals must be recognized as invalid by the court according to the legislation, and the employee must be called to disciplinary liability.

Speaking about the state civil service, we should notice that the Federal law from June 27, 2004 «About the state civil service of the Russian Federation», states that the individual after dismissal from the civil service has no right to take the posts within two years, neither to be hired on the basis of a civil contract in organizations in case if some functions of state administrations by these organizations constituted his immediate duties; reveal or use in the interests classified information or any other information for internal use only of these organizations which he was aware of while executing his duties (Article 17) ${ }^{15}$. The statements of the Labor Code of the Russian Federation protect the above-mentioned statement.

So, the Labor Code of the Russian Federation foresees the conditions of the labor agreement with the former civil and municipal servant. For instance, individuals who held the posts from the list established by the normative legal acts of the Russian Federation have to tell the employer about their last place of service during two years after dismissal from the state or municipal service.

In his turn, the employer when concluding the labor agreement with the individual who held the post at the bodies of municipal or civil service from the list established by the normative legal acts of the Russian

\footnotetext{
14 Legislation Bulletin of the Russian Federation. 2003. № 22. P. 2063.

15 Legislation Bulletin of the Russian Federation. 2004. № 31. P. 2063.
}

Federation during two years after dismissal from the civil or municipal service is obliged within 10 days to report about the conclusion of such an agreement to the representative of the employer (the employer) of the civil or municipal service from the last place of service in the order established by the normative legal acts of the Russian Federation (Article 64.1).

To reduce the level of unreasonable administrative discretion in the question of application of the administrative compulsion, in our opinion, the legal mechanism should be established in the Code of the Russian Federation on Administrative offences, which will not give the subjects of administrative jurisdiction the choice between the measures of preventative organizational character and administrative punishment in case of administrative offence. In all cases of administrative offences only administrative punishment should take place and not the measures of preventative organizational character.

However, the efforts of public authorities alone in the matter of corruption prevention may not be enough. In relation to this, the State urgently needs to support the civil society institutions, which are participating in corruption prevention campaigns. It would be appropriate to strengthen the forms of cooperation of the authorities, which are called to execute corruption prevention with the institutions of civil society; to create the administrative legal regime of protection of the individuals who are assisting the campaigns aimed at corruption prevention in the civil service system of the Russian Federation, and probably even stimulate their activities in some cases by means of paying simultaneous financial rewards. For efficient work of the administrative legal means, their coordination and application as a whole are important. It is worth mentioning that administrative legal means should be realized in consistency throughout the civil service system - meaning civil system, military and law enforcement service at one time. At the same time it is important to take into consideration the specific character of various means of the civil service. But all types of civil service still need to have common administrative legal 
means of corruption prevention. In particular, a universal administrative legal means of corruption prevention may be considered the mechanism of control of the income and property of the state civil servant, officer of the law enforcement service, including a military servant who hold the post of the medium, senior and highest commanding staff. The specific character of every type of the civil service requires its working out and realization, its specific administrative and legal means of corruption prevention.
In conclusion, we would like to say that especially today it is urgent to realize the whole normative, organizational and informational potential of legal mechanism of the corruption prevention in the civil service system of the Russian Federation. Positive results in corruption prevention can only be truly achieved if all the means of corruption prevention are applied at the same time and this will cause the corruption reduction to the level when it does not mean serious threat to the individual, society and State.

\section{References:}

1. Koryakin V.M. Corruption in Armed Forces: theory and practice of prevention. M., 2009.

2. Kostennikov M.V., Kurakin A.V. Topical issues of the science of administrative law. M., 2011.

3. Kostennikov M.V., Kurakin A.V. Administrative prohibition as a means of corruption prevention in the civil service system. M., 2010.

4. Kurakin A.V. Topical issues of administrative legal regulation. M., 2011.

5. Kurakin A.V. Administrative law: theory issues and development perspectives. M., 2013.

6. Luneev V.V. Corruption in Russia // State and Law (Journal). 2007. № 11.

7. Malinovsky A.A. Professional ethics code: the notion and legal meaning // Journal of Russian Law. 2008. № 4.

8. Nozdrachev A.F. Legal means of corruption prevention // Journal of Russian Law. 2004. № 9.

9. Panova I.V. Administrative jurisdiction in Russia: search for determination, history of the question: extract // Bulletin of the Supreme Arbitration Court of the Russian Federation. 2009. № 3.

10. Sukharenko A.N. State and society against corruption. Vladivostok 2013.

11. Khabibulin A.G. Corruption as a threat to national safety: methods, issues and ways of solving them // Journal of Russian Law. 2007. № 2. 